\title{
The Effect of Family Background and Socioeconomic Status on Academic Performance of Higher Education Applicants
}

\author{
Seyed Bagher Mirashrafi \\ Karlsruhe Institute of Technology, Germany and University of Mazandran, Iran \\ Georg Bol, Gholamreza Nakhaiezadeh \\ Karlsruhe Institute of Technology (KIT), Germany
}

\begin{abstract}
This paper analyzes the effect of different aspects of family background such as family income, parental education, parental job, and the socioeconomic status of parents on the university admission in Iran in 2008. The Iranian university and college admission system involves prospective students listing up to one hundred majors in order of their preference in the application. Places in universities are offered to the applicants based on both their preferences and their entrance examination results.

The gathered data from the Iranian university and college applications in 2008 is analyzed using data mining methods to investigate the effects of family background variables on entrance examination grades. The results of this analysis show that parental education, parental job and the socioeconomic status of family have large effects on entrance examination grades, and as a result on university and college acceptance.

The proportion of acceptance in universities for high social class families are more than the proportion of candidates in the other categories. In other words, applicants who come from higher social classes have a significantly better chance of becoming admitted in university.
\end{abstract}

\section{Introduction}

The Iranian university and college admission system requires prospective college and university students ranking up to one hundred majors in order of their preference after receiving their examination grade. The National Organization for Educational Testing (NOET) processes applications for all different kinds of university admissions at all levels.

The nationwide exam is held in five groups: mathematics and physics, empirical sciences, human sciences, art and language. Typically, seven to ten subjects are examined in each group. Table 1 shows these examined subjects. Four general subjects are common in all groups: Farsi Literature, Arabic Language, Islamic Literature, and Foreign Language.
Table 1. Names of specialized subjects in each group

\begin{tabular}{|l|c|}
\hline \multicolumn{1}{|c|}{ Testing Group } & Examined Subjects \\
\hline $\begin{array}{l}\text { Mathematics and } \\
\text { Physics }\end{array}$ & Mathematics, Physics, Chemistry \\
\hline Empirical Sciences & $\begin{array}{c}\text { Mathematics, Physics, Chemistry, } \\
\text { Biology, Geology }\end{array}$ \\
\hline Human Sciences & $\begin{array}{c}\text { Mathematics, Economics, History } \\
\text { and Geography, Social Sciences, } \\
\text { Philosophy and Logic, Psychology }\end{array}$ \\
\hline Art & $\begin{array}{c}\text { Mathematics, Art Information, } \\
\text { Technical Drawing, Music, Picture } \\
\text { and Imagination ability, Play Skills }\end{array}$ \\
\hline Language & Specialized Language \\
\hline
\end{tabular}

Once assessed, for each subject, the examination results are used to produce a score between -33 and 100 per candidate. The structure of exams is based on multiple choices and every three wrong answers are considered as one negative point. In other words, if a candidate has three wrong answers and one correct answer, his or her mark is equal to zero.

Subsequent to examination grading, the NOET fixes a total mark for each candidate following a certain process. The points requirements are set so that applicants are offered a place in the highest preference major for which they are eligible; in the case of candidates being tied for the last position in a field, both are offered a place. It should be emphasized that candidates do not know the field point's requirement prior to completing their application or taking their examination. The point's requirement is influenced by the examination results of candidates who applied for each major and by the number of available positions in that major.

Some fields have minimum entry standards. For example, sufficient knowledge of mathematics may be required for an engineering level. A few fields in the Art group have interviews, but these are not common. The candidates who apply within the first three groups are also allowed to apply for the Art and Language groups, but not vice versa. 


\section{Literature Review}

After a brief review of the Iranian university and college admission system, the impact of family background on applicants' examination result is discussed. This paper is a contribution to general debate of educational attainment.

Social scientists have developed sophisticated models for educational attainment using different causal variables $[1,5]$. Although, there are variations regarding race and sex e.g. $[6,11]$, the same causal variables have been applied generally. Considerable variation in educational outcomes is not explained by the basic attainment model $[3,8]$.

Past research has indicated an academic achievement gap between the sexes, with boys ahead of girls. However, more recent study has shown that the achievement gap has been narrowing and that in some instances girls have higher academic achievement than boys [2]. Additionally, studies show that girls perform better in reading than boys. However, males are found to outperform females in mathematics and science [4].

Research has found that socioeconomic status, parental involvement, and family size are particularly important factors [12]. Lochner \& Belley [10] find that post-secondary (PS) attendance (and attendance at four-year PS institutions) is strongly positively related to parental income in the U.S., even after controlling for similar measures of family background and adolescent cognitive achievement. The effect of parental income PS attendance relationship in Canada is also positive, but substantially weaker.

The findings of Pedrosa et al [15] indicate that students coming from a disadvantaged environment, in socioeconomic and educational terms, perform relatively better than those coming from higher socioeconomic and educational strata. More interestingly, from an educational public policy viewpoint, students who came from public schools had a relatively better performance than those who had studied at private schools.

On the other hand, the expansion of universities caused some social changes in middle and low class categories. Hence, acceptance in the universities became one of the possible ways of having a better job and other economic opportunities. Getting a university degree may increase the chance of a change of social class from a low class to a high class.

Therefore, as mentioned above in the literature, there is a variety of theories on the effects of family background in educational attainment. For example, Khodaei [9] shows that parental education has positive effects on the children's success, from an educational point of view.

Moreover, Jamali shows the increase of parent's educations level and father job's causes the increase of educational performances [7]. Additionally, all of these results in this study supported as well as the Mirashrafi et al $[13,14]$ research.

Sacker and her colleagues set out to test the model shown in figure 1. Sacker et al [16] set out to examine how inequalities in educational achievement and adjustment come about. It has been well known for decades that pupils' educational achievement is related to parents' social class yet the mechanisms that form this relationship are not well understood. How does social class influence school achievement?

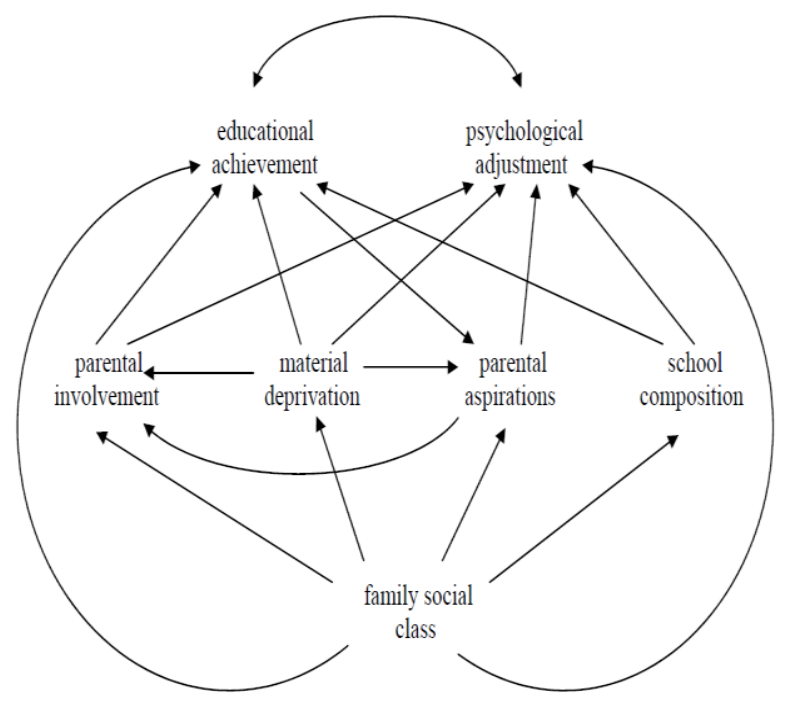

Figure 1. Sacker et al model of the relationship between family social class, and pupil achievement and adjustment.

Furthermore, the growth of the population rate and decline in the mortality rate at the same time, have led to an increased demand for education. Therefore, governments invest more in higher education. This situation happened in Iran after the Islamic Revolution of 1979. Because of some unsuccessful policies, the growth of the population rate went up sharply and, simultaneously, the demands for higher education increased considerably. Hence, the Iranian government started to expand universities to deal with the high demand for higher education.

\section{Methodology}

This study deals with two main questions. First, does family background such as parental education, family income and parental job have any effects on Iranian universities admission? Second, is there any difference between percentages of becoming admitted among different social classes in Iran?

In this study we consider acceptance in universities and total marks as dependent variables and parental education, family's income, parental job, gender and age of participants as independent variables. 
As a result, we use data mining methods to answer those two questions. For univariate analysis of variance, descriptive of the full sample and socioeconomic status of low, mid, and high levels were performed. The descriptive factors included min, max, mean, median and standard deviation. Furthermore, analysis of variance (ANOVA) was run across the low, mid, and high socioeconomic status levels for each family background factor.

\section{Data and Descriptive Analysis}

The dataset, which is used in this analysis, contains two parts. Part one consists of applicants' specifications such as gender, testing group, age, total grade and acceptance as well as information about their application in 2008 from the NOET's original data file. The second part of data is extracted from a questionnaire with four questions regarding applicants' family background, which is filled by all applicants during the nationwide examination. These two files are merged into one dataset according to the applicants' ID. Table 2 shows a description of variables used in the analysis.

Table 2. Description of variables used in analysis

\begin{tabular}{|c|c|c|c|}
\hline Variable Name & Valuc & & Measure \\
\hline Age & $\begin{array}{l}\text { Min } \\
\text { Max } \\
\text { Mean } \\
\text { Median } \\
\text { Std. Dev. }\end{array}$ & $\begin{array}{l}14.00 \\
79.00 \\
20.77 \\
19.00 \\
3.84\end{array}$ & Scale \\
\hline Gender & $\begin{array}{l}\text { Female } \\
\text { Male }\end{array}$ & $\begin{array}{l}62.6 \% \\
37.4 \%\end{array}$ & Nominal \\
\hline Testing Group & $\begin{array}{l}\text { Mathematics } \\
\text { Empirical Sciences } \\
\text { Human Sciences }\end{array}$ & $\begin{array}{l}24.3 \% \\
36.1 \% \\
39.6 \%\end{array}$ & Nominal \\
\hline Total Grade & $\begin{array}{l}\text { Min } \\
\text { Max } \\
\text { Mean } \\
\text { Stdian Dev. }\end{array}$ & $\begin{array}{l}-4834.00 \\
13688.00 \\
5592.04 \\
5346.00 \\
1574.73\end{array}$ & Scale \\
\hline Acceptance & No & $63.0 \%$ & Nominal \\
\hline
\end{tabular}

\begin{tabular}{|c|c|c|c|}
\hline & Yes & $37.0 \%$ & \\
\hline $\begin{array}{l}\text { Father's } \\
\text { Education }\end{array}$ & $\begin{array}{l}\text { No Education } \\
\text { Primary School } \\
\text { High School } \\
\text { University Degree }\end{array}$ & $\begin{array}{l}18.0 \% \\
35.7 \% \\
31.1 \% \\
15.2 \%\end{array}$ & Nominal \\
\hline $\begin{array}{l}\text { Mother's } \\
\text { Education }\end{array}$ & $\begin{array}{l}\text { No Education } \\
\text { Primary School } \\
\text { High School } \\
\text { University Degree }\end{array}$ & $\begin{array}{l}27.7 \% \\
39.2 \% \\
26.3 \% \\
6.7 \%\end{array}$ & Nominal \\
\hline Father's Job & $\begin{array}{l}\text { Workless or Other job } \\
\text { Private Sector Employee } \\
\text { Government Employee } \\
\text { Teacher or Lecturer }\end{array}$ & $\begin{array}{l}17.4 \% \\
50.5 \% \\
25.9 \% \\
6.2 \%\end{array}$ & Nominal \\
\hline $\begin{array}{l}\text { Family's Income } \\
\text { (yearly in USD) }\end{array}$ & $\begin{array}{l}\text { Weak }(<3000) \\
\text { Average }(3000-5400) \\
\text { Good }(5400-7800) \\
\text { Very Good }(>7800)\end{array}$ & $\begin{array}{l}38.5 \% \\
42.1 \% \\
13.1 \% \\
6.3 \%\end{array}$ & Nominal \\
\hline
\end{tabular}

The used data file is the total number applicants and is not a sample. The variables in this study allow a reasonable replication of the educational attainment models, most commonly estimated ${ }^{l}$.

In 2008 the total number of applicants in the Iranian nationwide university entrance examination was $1,507,372$ persons. Language and art groups were floating groups and candidates could choose one of main groups (mathematics and physics, empirical sciences, human sciences) as well as either or both of these two groups. Therefore, after removing duplicated candidates 1,158,094 actual candidates were used in our analysis.

Table 3 shows the number and percentages of candidates and entrants by each group. It can be seen from this table that from 1,158,094 candidates 428,903 persons were accepted in universities; of which $38.5 \%$ are from group one, $25.3 \%$ are from group two and $36.2 \%$ are from group three. Hence, the chance of entrance for group one, two and three are $58.6 \%, 26.0 \%$ and $33.8 \%$ respectively.

\footnotetext{
${ }^{1}$ The categorization of variables such as family's income, parental education and parental job were coded in the NOET.
} 
Table 3. The number and percentage of candidates and entrants by testing group

\begin{tabular}{|l|c|c|c|c|c|c|c|c|}
\hline Group: & \multicolumn{2}{|c|}{$\begin{array}{c}\text { Math. \& } \\
\text { phys. }\end{array}$} & \multicolumn{2}{c|}{$\begin{array}{c}\text { Empirical } \\
\text { sciences }\end{array}$} & \multicolumn{2}{c|}{$\begin{array}{c}\text { Human } \\
\text { sciences }\end{array}$} & \multicolumn{2}{c|}{ Total } \\
\hline & No. & \% & No. & \% & No. & \% & No. & \% \\
\hline Candidates & 281,866 & 24.3 & 417,209 & 36.1 & 459,019 & 39.6 & $1,158,094$ & 100 \\
\hline Entrants & 165,227 & 38.5 & 108,425 & 25.3 & 155,251 & 36.2 & 428,903 & 100 \\
\hline Chance & & 58.6 & & 26.0 & & 33.8 & & 42.9 \\
\hline
\end{tabular}

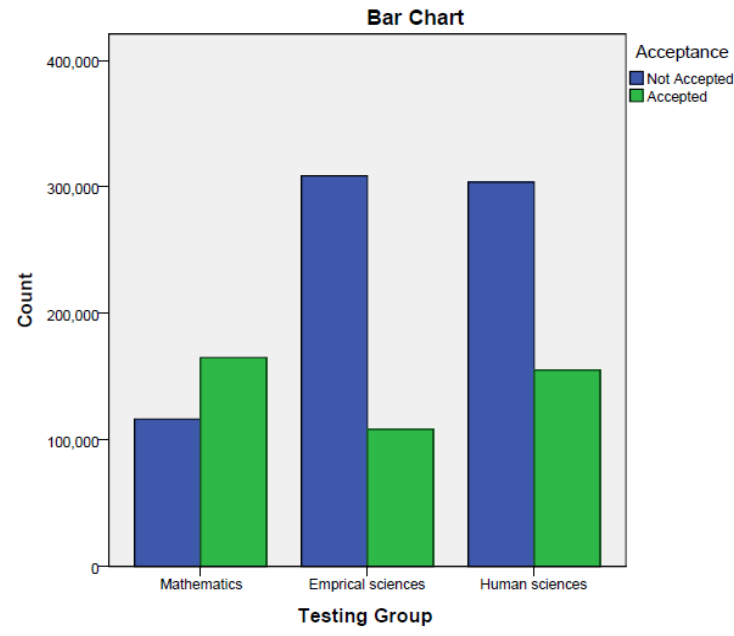

Figure 2. The chance of entrance to university in testing groups

The Figure 2 shows the group one candidate has a higher chance for entrance to university according to the other group candidates.

In the following section, we use the total grade of each candidate as a dependent variable and calculate cross-tabulations between the total grade and family background variables.

\subsection{Parental Education}

Table 4 and 5 compare total grade of applicants according to their parental education levels and the gender. The percentages of candidates according to the their father education in four categories of university degree holders, high school certificate holders, primary school certificate holders and with no educations are $15.2 \%, 31.1 \%, 35.7 \%$ and $18.0 \%$ respectively.

As can be seen from table 4 and figure 3 , the father's education has a positive effect on the total grades of candidates. With an increase in the father's level of education, the total grades of applicants increase. For example, the means of total grades in four categories are 6244.6, 5651.4, 5473.6, and 5284.9 .

This pattern is the same for both sexes and the only difference is that the mean of total grades for females is slightly higher than males.
Table 4. The mean of total grades of applicants by father's education and the gender of candidates

\begin{tabular}{|l|c|c|c|c|c|c|}
\hline & $\begin{array}{c}\text { No } \\
\text { educations }\end{array}$ & $\begin{array}{c}\text { Primary } \\
\text { school }\end{array}$ & $\begin{array}{c}\text { High } \\
\text { school }\end{array}$ & $\begin{array}{c}\text { Uni. } \\
\text { degree }\end{array}$ & F. & Sig. \\
\hline Male: & 5186.3 & 5304.5 & 5454.3 & 6009.8 & 4006.6 & 0.000 \\
\hline Female: & 5359.0 & 5560.9 & 5751.4 & 6419.3 & 10214.4 & 0.000 \\
\hline Total: & 5284.9 & 5473.6 & 5651.4 & 6244.6 & 13469.9 & 0.000 \\
\hline
\end{tabular}

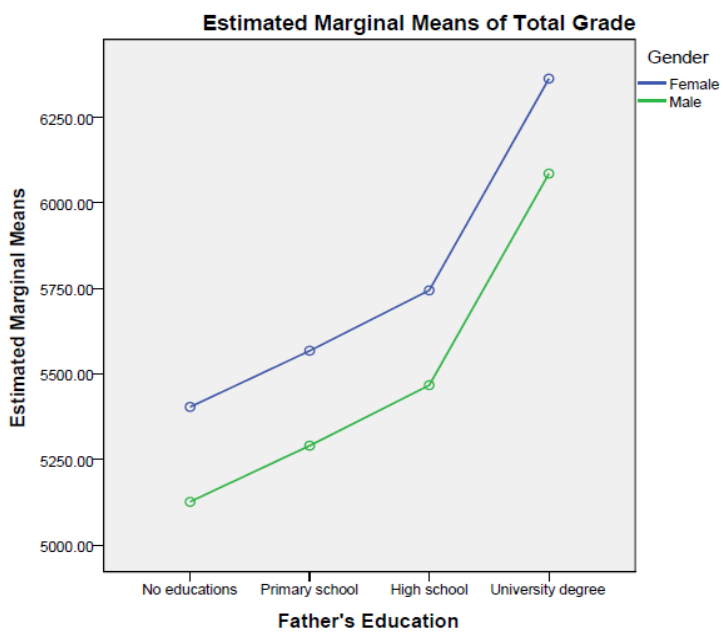

Figure 3. Estimated the mean of total grades by father's education and the gender of candidates

Table 5 and Figure 4 show the mean of total grades of applicants regarding their mother's education and the gender. In this table and figure we have the same pattern as in Table 4 and Figure 3. Hence, the education of mother has a positive effect on the mean of total grades of applicants.

In other words, the higher level of parental education is, in almost every case, associated with a higher mean of total grades of male and female applicants. The likelihood of entering the university is, in particular, much higher for the children of university-educated parents compared to the children of parents with any other educational level.

Table 5. The mean of total grades of applicants by mother's education and the gender of candidates

\begin{tabular}{|l|c|c|c|c|c|c|}
\hline & $\begin{array}{c}\text { No } \\
\text { educations }\end{array}$ & $\begin{array}{c}\text { Primary } \\
\text { school }\end{array}$ & $\begin{array}{c}\text { High } \\
\text { school }\end{array}$ & $\begin{array}{c}\text { Uni. } \\
\text { degree }\end{array}$ & F. & Sig. \\
\hline Male: & 5237.6 & 5346.5 & 5601.1 & 6162.5 & 3490.0 & 0.000 \\
\hline Female: & 5411.1 & 5610.1 & 5918.9 & 6737.8 & 10318.1 & 0.000 \\
\hline Total: & 5339.3 & 5522.7 & 5808.4 & 6468.9 & 12865.4 & 0.000 \\
\hline
\end{tabular}




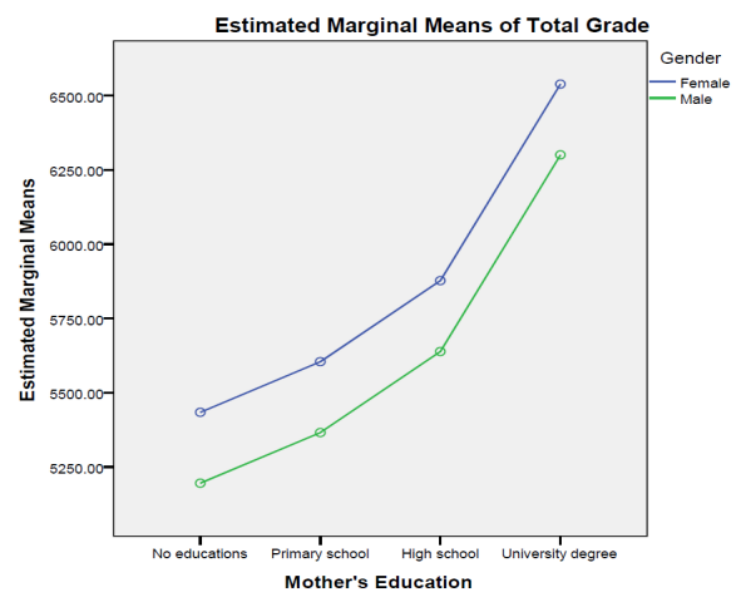

Figure 4. Estimated the mean of total grades by mother's education and the gender of candidates

\subsection{Father's Job}

Table 6 shows the mean of total grades of applicants relative to their father's job. The father's job is categorized into four categories: education related (teachers, university lecturers), governmental employee, private sector, and other jobs. The means of total grades were $6071.8,5733.3,5626.3$, and 5254.4, for applicants, whose fathers' jobs are educational related, government employee, private sector employee, and other respectively.

Table 6. The mean of total grades of applicants by father's job and the gender of candidates

\begin{tabular}{|l|c|c|c|c|c|c|}
\hline & $\begin{array}{c}\text { Other } \\
\text { jobs }\end{array}$ & $\begin{array}{c}\text { Private } \\
\text { sector }\end{array}$ & $\begin{array}{c}\text { Gov. } \\
\text { emp. }\end{array}$ & $\begin{array}{c}\text { Teacher or } \\
\text { lecturer }\end{array}$ & F. & Sig. \\
\hline Male: & 5148.1 & 5437.1 & 5566.2 & 5833.5 & 1608.0 & 0.000 \\
\hline Female: & 5333.0 & 5716.0 & 5830.0 & 6243.7 & 4188.4 & 0.000 \\
\hline Total: & 5254.4 & 5626.3 & 5733.3 & 6071.8 & 5762.3 & 0.000 \\
\hline
\end{tabular}

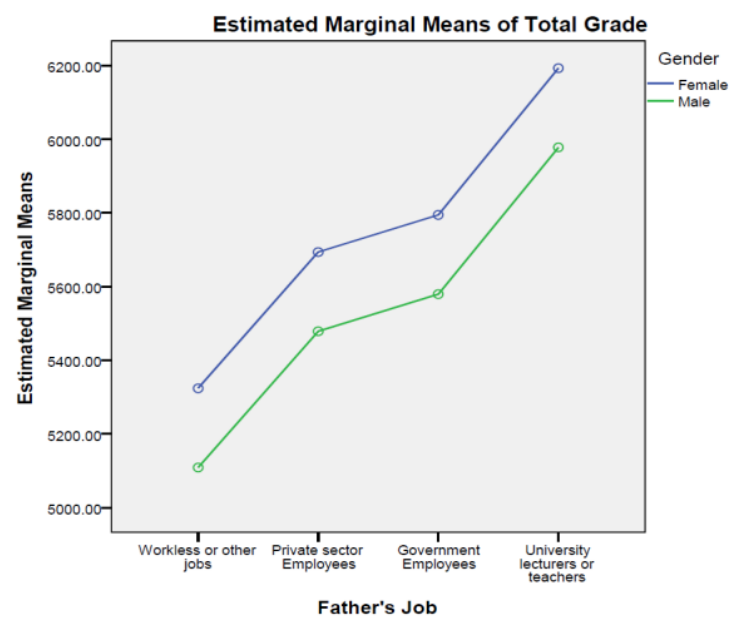

Figure 5. Estimated the mean of total grades by father's job and the gender of candidates

As can be seen from Table 6 and Figure 5, the mean of total grades for applicants whose fathers are teachers or university lecturers is more than other categories. However, the mean of total grades for those applicants whose father is a governmental employee is greater compared to the other two groups. Probably government employees provide better quality of care to children and try to construct a supportive environment for their children by encouraging them to study.

\subsection{Family's Income}

Table 7 shows the mean of total grades in 2008 regarding the applicants' family income and their gender. The family's income is grouped into four categories which are weak (<3000 USD), average (3000-5400 USD), good (5400-7800 USD), and very good (>7800 USD) yearly. The mean of total grades in four categories are 5385.8, 5611.7, 5965.8, and 6186.8 for applicants, whose family incomes are weak, average, good, and very good respectively.

Table 7. The mean of total grades of applicants by family's income and the gender of candidates

\begin{tabular}{|l|l|l|l|l|l|l|}
\hline & Weak & Average & Good & Very good & F. & Sig. \\
\hline Male: & 5231.3 & 5438.6 & 5806.9 & 5984.9 & 2882.9 & 0.000 \\
\hline Female: & 5479.5 & 5706.4 & 6058.0 & 6326.7 & 5974.3 & 0.000 \\
\hline Total: & 5385.8 & 5611.7 & 5965.8 & 6186.8 & 8673.4 & 0.000 \\
\hline
\end{tabular}

The mean of total grades for applicants whose family's income is good or very good are greater than the other categories. This pattern is the same for both sexes and the only difference is that the mean of total grades for females are slightly higher than for males'.

As can be seen from Table 7 and Figure 6, the family's income has a positive effect on the total grades of candidates. With an increase in the family's income, the total grades of applicants increase. Moreover, the result of ANOVA shows that the means of total grades of applicants have gone up with the family's income increase. 


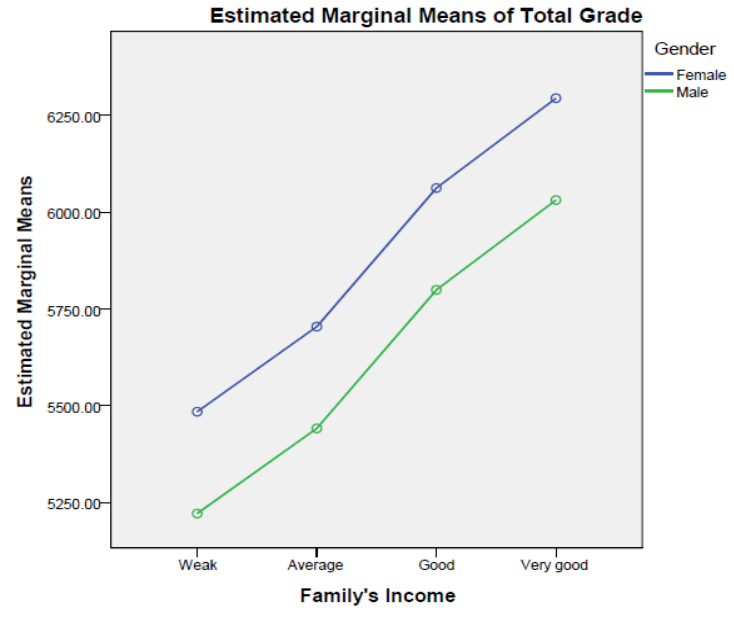

Figure 6. Estimated the mean of total grades of applicants by family's income and the gender

\subsection{Age of Participants}

Table 8 shows the subset of total grades according to the categorized participant's age. The age of participant is grouped into five categories which are younger than 18 years, 18 years, 19 years, 20 thru 22 years, and older than 22 years. The mean of total grades in five groups are 6201.8, 6189.6. 5961.7, 5209.2, and 4642.1 for applicants, whose age are younger than 18 years, 18 years, 19 years, 20 thru 22 years, and older than 22 years respectively.

Table 8. The mean of total grades of applicants by categorized participant's age

\begin{tabular}{|c|c|c|c|c|c|}
\hline \multirow{2}{*}{$\begin{array}{l}\text { Categorized Participant's } \\
\text { Age }\end{array}$} & \multirow[b]{2}{*}{ N } & \multicolumn{4}{|c|}{ Subset } \\
\hline & & 1 & 2 & 3 & 4 \\
\hline Older than 22 years & 162831 & 4642.0692 & & & \\
\hline 20 thru 22 years & 338455 & & 5209.1884 & & \\
\hline 19 years & 343916 & & & 5961.6835 & \\
\hline 18 years & 254233 & & & & 6189.6307 \\
\hline Younger than 18 years & 1889 & & & & 6201.7835 \\
\hline Sig. & & 1.000 & 1.000 & 1.000 & .572 \\
\hline
\end{tabular}

As a result from Table 8 and Figure 7, age of participant has a negative effect on total grades. That means if the age of candidate increased that caused the mean of total grades decreased.

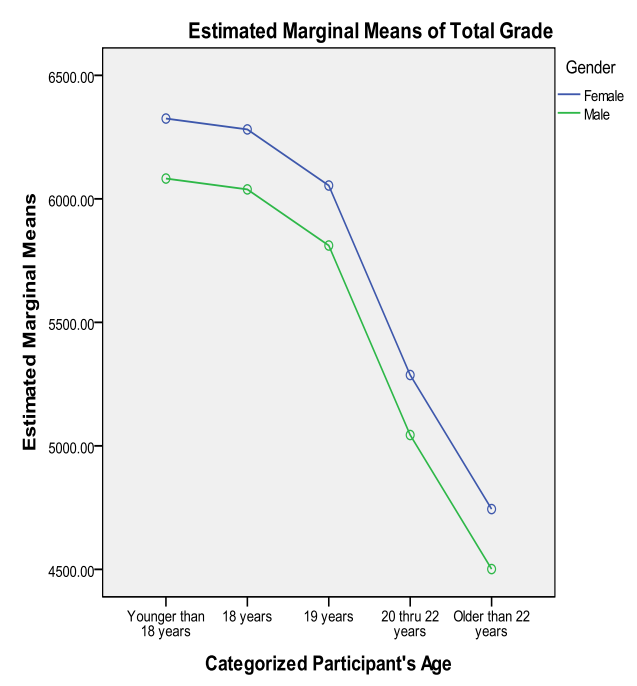

Figure 7. Estimated the mean of total grades of applicants by age of participants and the gender

\section{Inferential Analysis}

In this section the result of some inferential analysis such as logistic regression, linear regression and neural networks are presented.

\subsection{Binary logistic regression}

In this analysis, the dependent variable is the acceptance in universities and colleges, while the independent variables or covariates are age, gender, father's job, father's education, mother's education and family's income. In this analysis the stepwise method is used to determine the order of the variables importance.

Table 9. The coefficients and variables in the logistic regression model

\begin{tabular}{|l|l|l|l|l|l|}
\hline Variable name & B & S.E. & Wald & Sig. & Exp(B) \\
\hline Age & -0.127 & 0.001 & 24986.0 & 0.000 & 0.881 \\
\hline Mother's Ed. & 0.102 & 0.003 & 1017.9 & 0.000 & 1.107 \\
\hline Family's Inc. & 0.070 & 0.003 & 683.8 & 0.000 & 1.072 \\
\hline Father's Job & 0.055 & 0.003 & 311.1 & 0.000 & 1.057 \\
\hline Father's Ed. & 0.037 & 0.003 & 124.0 & 0.000 & 1.037 \\
\hline Gender & -0.029 & 0.004 & 45.8 & 0.000 & 0.972 \\
\hline (Constant) & 1.536 & 0.019 & 6211.3 & 0.000 & 4.644 \\
\hline
\end{tabular}

Table 9 shows how two variables, namely age and gender, have a negative effect on the acceptance in the universities. That means if the age of a candidate increased, he would have a less chance to get accepted in universities. The variables in table 8 are ordered according to their importance in the model. That means, in this model, the age is the most important factor affecting the acceptance in the universities and after that mother's education has the 
maximum effect and the gender has the minimum effect.

\subsection{Linear regression}

The linear regression analysis is used in which the dependent variable is the mean of total grade. This analysis is performed like the logistic regression in section 5.1, where the independent variables are age, gender, father's job, father's education, mother's education and family's income. Table 10 shows the order of the variables according to their importance in the linear regression model.

Table 10. The variables and coefficients in the linear regression model

\begin{tabular}{|l|l|l|l|l|l|}
\hline & \multicolumn{2}{l}{$\begin{array}{l}\text { Unstandardized } \\
\text { Coefficients }\end{array}$} & \multicolumn{2}{l|}{$\begin{array}{l}\text { Standardized } \\
\text { Coefficients }\end{array}$} & \\
\hline Variable name & B & Std. Error & Beta & t & Sig. \\
\hline Age & -116.77 & 0.403 & -0.271 & -290.0 & 0.000 \\
\hline Family's Inc. & 141.99 & 1.893 & 0.078 & 75.0 & 0.000 \\
\hline Father's Ed. & 71.08 & 2.319 & 0.043 & 30.7 & 0.000 \\
\hline Gender & -223.81 & 2.984 & -0.069 & -75.0 & 0.000 \\
\hline Mother's Ed. & 83.45 & 2.264 & 0.047 & 36.8 & 0.000 \\
\hline Father's Job & 38.87 & 2.197 & 0.020 & 17.7 & 0.000 \\
\hline (Constant) & 7629.16 & 11.041 & & 691.0 & 0.000 \\
\hline
\end{tabular}

\subsection{Neural networks model}

The neural networks have been used for predictive purposes, i.e. not only for classification but also for regression of continuous target attributes. Figure 8 shows the most important variables based on the final model, which are age of participant, mother's education, family's income, father's job, father's education and gender respectively. The analysis of this model has an approximate $63.6 \%$ accuracy in classification of the acceptance in the universities.

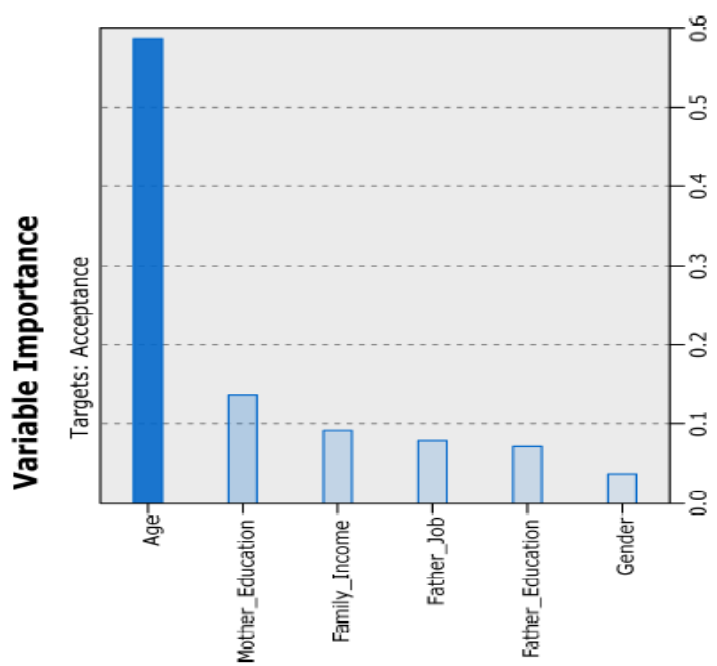

Figure 8. The neural networks results for classification
Figure 9 shows the neural networks results of prediction model, in which independent variable is the mean of total grade. Due to this model age, mother's education, father's education, gender, family's income and father's job are considered the most important variables respectively. The analysis of this model has an approximate $41 \%$ linear correlation in prediction of the mean of total grade.

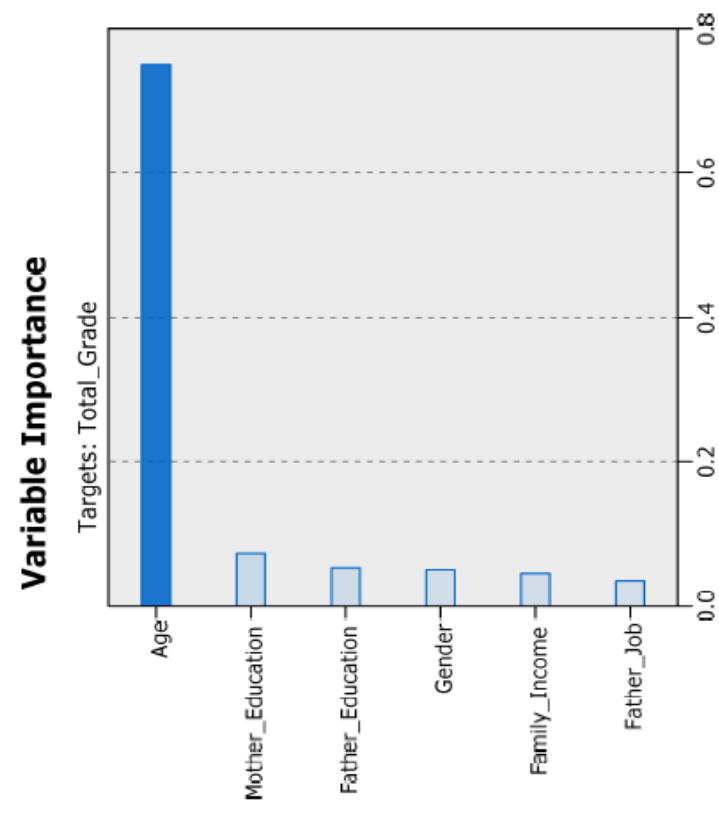

Figure 9. The neural networks results for prediction

\section{Conclusions}

It can be concluded that, in most cases, the mean of total grades for male applicants fell further behind the total grades of their female peers according to the following variables: parental education, parental job, and family's income. Additionally, female grades increased marginally at all higher parental education levels and increased substantially for applicants with university-educated parents.

The data mining methods and regression models show that all of the family background factors influence on participates' educational achievement. Some factors have positive effects on the mean of total grades such as: parental education, parental job and family's income. Additionally, the age of applicants has a negative effect on the candidates' educational achievement.

Neural Net analysis indicated an additional point of view in this study. Due to this analysis the important factors on educational achievement are age, father's education, family's income, mother's education, father's job, and gender respectively. 


\section{References}

[1] Blau, P. M., \& Duncan, O. D. (1967), "The American occupational structure", New York: Wiley.

[2] Chambers, E. A. and Schreiber, J. B. (2004), "Girls academic achievement: Varying associations of extracurricular activities." Gender and Education, 16, 327346.

[3] DiMaggio, P. (1982), "Cultural capital and school success: The impact of status cultural participation on the grades of U.S. high school students." American Sociological Review, 47, 189-201.

[4] Eitle, T. M. (2005), "Do gender and race matter? Explaining the relationship between sports participation and achievement", Sociological Spectrum, 25, 177-195.

[5] Featherman, D. L. and Hauser, R. M. (1978), "Opportunity and change" New York: Academic Press.

[6] Gottfredson D. C., (1981), "Black-white differences in the educational attainment process: What have we learned?" American Sociological Review, 46, 542-557.

[7] Jmali, E. (2011), "The effects of socioeconomic status on educational performance of higher education applicants in Iran." Journal of Higher Education in Iran, 10, 25-54.

[8] Jencks C., Crouse J., Mueser P. (1983), "The Wisconsin model of status attainment: A national replication with improved measures of ability and aspiration." Sociological Education, 56, 3-19.

[9] Khodaei, E. (2009), "A study on the relationship between parental socio-economic capital and the probability of students' acceptance in the 2006 nationwide examination of Iran.” Journal of Higher Education in Iran, 4, 65-84.

[10] Lochner, L. \& Belley, P., "Educational attainment by parental income: a Canada - U.S. comparison" The Boston University Econometrics Seminar, November 2008.

[11] Marini, M. M. (1978), "Sex differences in the determination of adolescent aspirations: A review of research.” Sex Roles, 4, 723-753.

[12] Majoribanks, K. (1996), "Family learning environments and students' outcomes." Journal of Comparative Family Studies, 27, 373-394.

[13] Mirashrafi, S. B., et al, "The impact of family background and socioeconomic status on university admission in Iran." $14^{\text {th }}$ Annual International Conference on Education, Athens, Greece, May 2012.

[14] Mirashrafi, S. B., et al, "The impact of family background and socioeconomic status on university admission in Iran in 2009." Canada International Conference on Education, Ontario, Canada, June 2012.
[15] Pedrosa, R. H. L., et al, "Educational and socioeconomic background of undergraduates and academic performance: consequences for affirmative action programs at a Brazilian research university." IMHE/OECD General Conference, Paris, September 2006.

\section{Acknowledgements}

The authors are very grateful to the National Organization for Educational Testing of IRAN for providing the database of all applicants applying for the nationwide exam in 2008. 
International Journal of Technology and Inclusive Education (IJTIE), Volume 2, Issue 1, June 2013

[16] Sacker, A., Schoon, I., and Bartley, M. (2002), "Social inequality in educational achievement and psychological adjustment throughout childhood: magnitude and mechanisms." Social Science and Medicine, 55, 863-880. 